\title{
САНАТОРНА РЕАБІЛІТАЦІЯ ДІТЕЙ ТА ПІДЛІТКІВ 3 ПАТОЛОГІЄЮ ТА ФУНКЦІОНАЛЬНИМИ РОЗЛАДАМИ БІЛІАРНО СИСТЕМИ IЗ ЗОН РАДІОАКТИВНОГО ЗАБРУДНЕННЯ ВНАСЛІДОК АВАРІ НА ЧАЕС
}

\author{
СД. В. Козак, О. М. Лавриненко, В. Б. Коваль, І. М. Салайда, В. В. Грушко \\ ДВНЗ «Тернопільський державний медичний університетімені І. Я. Горбачевського МОЗ України»
}

РЕЗЮМЕ. Робота присвячена вивченню ефективності впливу санаторно-курортно реабілітаці за допомогою природних лікувальних факторів та курсу ЛФК на перебіг хронічного некалькульозного холециститу та функціональних розладів біліарно системи у дітей та підлітків з радіоактивно забруднених територій внаслідок аварі на ЧАЕС КЛЮЧОВІ СЛОВА: Радіоактивне забруднення, хронічний холецистит, дискінезія жовчних шляхів, реабілітація.

Вступ. Хронічна патологія печінки $є$ однією з найгостріших проблем сучасно гастроентерологі [1]. В основному вона представлена хронічними гепатитами, на які хворіє $5 \%$ населення планети. В Укра ні за останні 5 років захворюваність на хронічні гепатити зросла на 76,6\%, поширеність хронічних гепатитів за цей період збільшилась в 2,2 раза [2]. У пацієнтів із хронічними гепатитами існує високий ризик переходу ціє патологі в цироз печінки та гепатоцелюлярну карциному $[3,4]$.

Вивченню особливостей перебігу хронічно патологі та функціональних розладів біліарно системи на бальнеологічних курортах присвячена значна кількість досліджень. Разом з тим, питанням фізично та медично реабілітаці пацієнтів, що проживають на територіях, які зазнали радіоактивного забруднення після аварі на ЧАЕС, приділяється, на жаль, недостатня увага [5].

Мета дослідження - вивчення ефективності фізично та медично реабілітаці дітей та підлітків, хворих на хронічний некам'яний холецистит та функціональні розлади біліарно системи, із зон радіоактивного забруднення після аварі на ЧАЕС, в умовах санаторію «Медобори», з використанням у лікувальному комплексі місцевих природних факторів (мінеральна вода «Медоборівська», торфоболото) та курсу ЛФК.

Матеріал і методи дослідження. Ми вивчали ефективність фізично та медично реабілітаці 53 дітей та підлітків із захворюваннями (хронічний некам'яний холецистит) та функціональними розладами (дискінезі жовчних шляхів) біліарно системи, з територій радіоактивного забруднення після аварі на ЧАЕС, головним чином із Рівенсько , Ки всько та Житомирсько областей.

У комплекс санаторно-курортного лікування входили: базова терапія середньомінералізованою (5 гр/дм ${ }^{3}$ ) хлоридно-натрієво-кальцієвойодо-бромною, з вмістом мікроелементів $\mathrm{Fe}, \mathrm{L}, \mathrm{Ag}$, мінеральною водою «Медоборівська»; дієтичне харчування; морські ванни; озокерито- та пело дотерапія (торфо-гальвано-болото); гідропатія (душ циркулярний, підводний душ-масаж); психотерапія та курс ЛФК (запропоновано лікувальну гімнастику, комплекс вправ, які проводяться при хронічному холециститі та дискінезі жовчних шляхів). Після проведено лікувально фізкультури хворим пропонували відпочинок впродовж 2030 хв, лежачи на лівому боці. Крім цього, для підвищення ефективності лікування рекомендовано було протягом дня хворим самостійно виконувати 3-5 спеціальних вправ, які сприяють відтоку жовчі.

Для оцінки ефективності проведено реабілітаці , окрім фізикальних методів, використовували УЗД, лабораторні (біохімічні), тести - динаміка рівня сіалових кислот, С-реактивного білка (СРБ), холатів, холестерину [6].

Результати й обговорення. Спостерігали позитивну динаміку клінічних проявів: у 91,2 \% пацієнтів суттєво зменшилися, за частотою та інтенсивністю, больові та неприємні відчуття у правому підребер' (зоні проекці жовчного міхура), в 93,6 \% у гастродуоденальній ділянці, гіркота в роті-у $88,1 \%$, печія, метеоризм - відповідно у 87,8 та $77,9 \%$.

Про поліпшення стану здоров'я досліджуваних свідчать і дані параклінічних методів обстеження. Під час повторного УЗД наприкінці реабілітаційного курсу у 83,4 \% випадків було відзначено лізис потовщення стінок й зменшення розмірів жовчного міхура, підвищення ехогенності його порожнини, розрядка гіпертонусу сфінктера Одді та застою жовчі в екстра- та інтрапечінкових відділах біліарно системи.

Повторні дослідження міхурово жовчі виявило (рис. 1) тенденці до зниження рівня сіалових кислот з $(125,08 \pm 11,28)$ до $(85,52 \pm 9,07)$ одиниць оптично щільності $(p<0,01)$, (СРБ) - $3(1,37 \pm 0,15)$ до $(0,69 \pm 0,57)$ млм $(\mathrm{p}<0,01)$, росту вмісту холатів 3 $(5,98 \pm 0,52)$ до $(7,54 \pm 0,56)$ г/л $(p<0,05)$, зниження рівня холестерину з $(1,20 \pm 0,46)$ до $(1,04 \pm 0,32)$ млм $(p<0,05)$, що зумовило зростання індексу літогенності (співвідношення холатів до холестерину) 3 4,98 до 7,25 ( $p<0,001)$.

Наведені показники свідчать про суттєве зменшення активності запального процесу, поліпшення синтезу холестерину в печінці та коло дного стану жовчі і $є$ об'єктивним доказом ефективності 


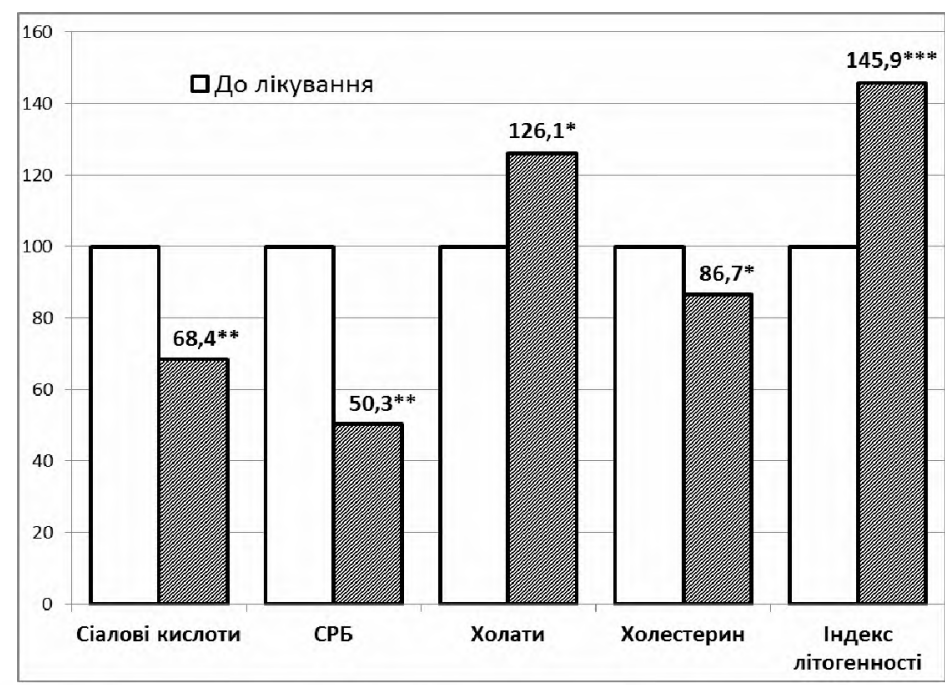

Рис. 1. Динаміка показників міхурово жовчі в ході лікування (у відсотках до вихідного стану) (* - достовірність відміностей стосовно стану до лкування: * - $<<0,05$; ** $-p<0,01$; *** $-p<0,001)$.

використання в санаторно-курортній реабілітаці дітей та підлітків із хронічним некам'яним холециститом та функціональними розладами біліарно системи (дизкінезі жовчовивідних шляхів) природних лікувальних факторів - мінерально води «Медоборівська", озокерито-, пело дотерапі та запропонованого курсу ЛФК.

Висновки. Позитивна динаміка клінічного перебігу та інструментально-лабораторних тестів у процесі медично реабілітаці, з використанням мінерально води «Медоборівська», місцевого торфоболота та запропонованого курсу ЛФК, у дітей та підлітків, хворих на хронічний некальку-

\section{ЛІТЕРАТУРА}

1. Сімейна медицина / За ред. В. Б. Гощинського, Є. М. Стародуба. - Тернопіль : ТДМУ, 2005. - 810 с.

2. Хвороби органів травлення (діагностика і лікуван ня) / Григор'єв П. Я. [та ін.] - Тернопіль : Укрмедкнига, 2000. $-448 \mathrm{c}$.

3. Окороков А. Н. Лечение болезней внутренних органов / А. Н. Окороков. - Т. 1. - М. : Мед. Лит., 2001. - 560 с.

4. Сучасні класифікаці та стандарти лікування розповсюджених захворювань внутрішніх органів / За ред. д.м.Н., проф. Ю. М. Мостового. -7-е вид., доп. і перероб. Вінниця, 2005. -479 с. льозний холецистит та функціональні розлади біліарно системи, з радіоактивно забруднених територій внаслідок аварі на ЧАЕС, вказує на ефективність фізично і медично реабілітаці зазначеного контингенту хворих в умовах санаторію «Медобори».

Перспективи подальших досліджень. Санаторно-курортна реабілітація $є$ важливим етапом у комплексі лікувально-профілактичних заходів стосовно пацієнтів із хронічними запальними захворюваннями та функціональними розладами біліарно системи і може бути використаною для лікування хворих із даною патологією.

5. Корнєєв Б. І. Реабілітація хворих на хронічний калькульозний холецистит із використанням мінерально води Зб ручанського родовища / Б. І. Корнєєв // Актуальні питання реабілітаці гастроентерологічних хворих. - Чернівці, 1996. - С. 175-177.

6. Чумак Я. П. Реабилитация ликвидаторов аварии на ЧАЭС в условиях курорта «Миргород» / Я. П. Чумак, Э. В. Бован, Р. В. Луценко // Физические лечебные факторы в медицинской реабилитации. - Одеса, 1996 С. $204 .-205$.

\title{
SANATORIUM REHABILITATION OF CHILDREN AND ADOLESCENTS WITH DISORDERS AND FUNCTIONAL DISORDERS OF THE BILIARY SYSTEM FROM ZONES OF RADIOACTIVE CONTAMINATION OF CHERNOBYL ACCIDEN
}

\author{
CD. V. Kozak, O. M. Lavrynenko, V. B. Koval, I. M. Salayda, V. V. Grushko \\ SHEI «Ternopil State Medical University by I. Ya. Horbachevsky of the MPH of Ukraine»
}

SUMMARY. The article deals with study of the effectiveness of sanatorium rehabilitation using natural healing factors and exercise course on the course of chronic non-calculous cholecystitis and biliary system functional disorders by children and adolescents from radioactively contaminated areas of Chernobyl accident.

KEYWORDS: radioactive contamination, chronic cholecystitis, biliary dyskinesia, rehabilitation. 